\title{
The Use of Colours in Marketing in Shopping Malls of Mauritius- A Gendered Approach
}

\author{
Thanika Devi Juwaheer \\ University of Mauritius \\ Kooldeep Sahye \\ University of Mauritius
}

Colours play a vital role in marketing and the way that consumers behave towards a product, service or company. Men and women view colours from different perspectives and this raises the need to understand the psychology of customers. The objective of this study is to determine if colours play any importance when men and women purchase their products respectively. This study also focuses on the product types' and colours that men and women are most interested during purchase of products and services. The last objective of this study is to find out if men and women associate different meanings with different colours and how marketers can take such perspectives into account when devising their marketing strategies.

A survey was carried out with 150 respondents aged between 18 to 25 years old by using quota sampling, whereby the same amount of men and women were involved. The results showed that both men and women are equally interested in colours in marketing and are both physically and physiologically affected by this marketing phenomenon. The results also show that men and women have common favourite colours for products and associate different colours with different meanings.

Keywords: Colours in Marketing, Shopping Malls, Gender and Influence of Colours, Marketing Strategies, Quota Sampling, Choice of Favourite Colours

\section{INTRODUCTION}

Colours are everywhere, from the clothes we wear, to the environment we live in, to the food we eat and to the products we use. Our brain assimilates about $80 \%$ of visual information everyday (Khouw, 2002). Colours have been said to attract customers, increase sales, help in product loyalty, differentiate products, and have different meanings attached to them (Sliburyte et al. 2014), but to which extent these factors affect the shopping habits of men and women, are yet to be explored. Researches on colours and its effect on gender has been widely studied upon, namely by Babolhavaehji (2015), Westland (2015), Chang (2010), Nezhad (2013), Khouw (2002), Akcay (2012, 2013 and Sliburyte (2014). However, the roles of men and women have seen a drastic change over the years and gender roles are no longer the same across respective purchase behaviour and the consumer decision-making process. Men and women are crossing stereotype barriers and making use of products that are not congruent to their gender. 
Exploring the minds of consumers can be tricky as their perceptions keep on changing on the exposure to new experiences but colours has demonstrated to be stabilised in the minds of the consumers. The use of colours as an approach to gendered marketing is not a new area of study since some previous researches have already been carried out, namely by Babolhavaehji (2015), Westland (2015), Chang (2010), Nezhad (2013), Khouw (2002), Akcay (2012), Sliburyte (2014), Akcay (2013), and Akcay (2011). However, the roles of men and women have seen a drastic change over the years and gender roles are no longer like before. Men and women are crossing barriers and making use of products that were once reserved for a specific gender only (Alreck, 1994). Thus, this raises the need for continuous research about men and women and their changing behaviours. Colour is the instrument used in this research to discover differences, if there exist any, between men and women.

Colours are everywhere, from the clothes that we wear, to the environment that we live in, to the food that we eat and to the products that we purchase. Our brain assimilates about $80 \%$ of visual information every day (Khouw, 2002). Thus, it is logical that marketers use this aspect of our lives to market their products. Colours play a vital role in our life, and we are all affected by it. This research is mostly focused on colours and takes into account how colours impact our purchases and perceptions as a consumer. Exploring the minds of consumers can be tricky as their perceptions keep on changing due to the exposure to new experiences but colours in marketing have demonstrated to be having a high level of impact on the minds of the consumers.

The purpose of this paper is therefore to determine the importance of colours from a gendered perspective when men and women purchase products, to find out which product types' colours men and women are more interested in and to identify the meaning associated with colours respectively.

Colours have been said to attract customers, increase sales, help in product loyalty and much more (Sliburyte et al. 2014). Understanding how Mauritian customers view colours and which colours affect them most is a crucial element in marketing. A questionnaire was designed and quota sampling was used to collect data from 150 respondents. The results concluded that colours in marketing need to be considered by companies when devising marketing strategies if they want to succeed from both strategic and competitive perspectives.

The present research aims at answering some questions pertaining to colours and consumer behaviour, more specifically, how men and women may or may not react differently to different colours. This research will be of great help in aiding marketers to understand how customers behave during purchase decisions and whether focus on colours in marketing from a gendered perspective is a significant variable to consider. This research is mostly focused on colours and takes into account how colours impact the purchase decisions and perceptions of consumers.

\section{RESEARCH OBJECTIVES AND RESEARCH QUESTIONS}

The objectives of this research are:

1) To determine the importance of colours when men and women purchase products from a marketing perspective.

2) To find out which product types' colours men and women are more interested in.

3) To identify the meaning associated with colours in marketing by men and women.

The research questions for the study are:

1) Does colour play a crucial role in the buying process of men and women?

2) Are men and women interested in the same product types' colours?

3) What is the most appreciated colour by both men and women?

4) Do colours have meanings for men and women in marketing campaigns and purchase decisions?

5) What meanings and attributes are associated with the different colours from a gendered perspective? 


\section{LITERATURE REVIEW}

\section{Colours in Marketing}

Colours have been used in marketing to differentiate products, create competitive advantage, increase sales, motivate impulse buying and repeat purchases, incur positive emotions on consumers, encourage people to stay longer and create emotional attachment (Sliburyte et al. 2014). Package colours help to attract attention, provide communication, give expectations, and depict the aesthetic experience of a product (Kauppinen - Räisänen, 2010) Kerckhove (2014) also put forward that consumers prefer combinations of similar colours when coloured products have a sense of 'belongingness' and contrasting colours when products have a sense of 'addition'. Colour increases your willingness to read, improves decision making process, increase customer retention, helps people recognise the products. Hence marketers may make use of colours to position a particular product and target it to a particular gender. Colour plays an important role in attracting customers and increasing sales. About $80 \%$ of information that our brain assimilates is visual (Khouw, 2002).

Colours help product differentiation as your customers are able to differentiate your product from that of your competitors. Colours can also create a competitive advantage and create emotional attachment. Colours help in creating and maintaining loyalty, increasing product sales, increasing impulse buying, and repeat purchases. The colour of a store can also encourage people to stay longer and people perceive your brand better with an attractive colour. Colour is also an inexpensive tool that can be used to create positive emotions on consumers about a particular brand or product (Sliburyte et al. 2014). Colour concerns the store as well. Babin et al. (2003) found out that customers were more attracted to cool store interiors. Moreover, blue was the most dominant colour that was liked and the lighting of the store must be considered as well. Colour also affects the waiting time of customers, the design and layout of a store and brands in general. Many brands are easily recognised by their colour, such as red for Coca Cola or yellow for Shell (Singh, 2006).

Colour of packed products is also an important aspect of marketing. Package colours help to attract attention, provide communication, give expectations and depict the aesthetic experience of the product. Colours like yellow and red which are considered warm colours were noted to be more attractive. The package colour and product type must however be considered (Kauppinen - Räisänen, 2010). Kerckhove (2014) put forward that consumers prefer combinations of similar colours when coloured products have a sense of 'belongingness'. However, if the coloured products have a sense of 'addition', then contrasting colours would be best suited to use. This information is particularly helpful for companies marketing bundle of products.

It is also to be pointed out that colour does not impact the name of a product but the type of colour does affect the name of a product (Miller, 2005). Colour increases your willingness to read by $80 \%$, improves decision making process by $70 \%$, increases customer retention by $78 \%$, helps people recall a particular product by $60 \%$, increases attention of customers by $82 \%$ and increases potential sales by $80 \%$ (Kumar, 2007). Colour is also exploited by companies for their online presence. Zailskaitè-Jakšte et al. (2017) found out that the most common colours used by companies on their social media were black, brown, blue and grey. However, it is speculated that the North American colour preferences and their associations to different colours will prevail in the end, due to the building up of communication and the world becoming a global neighbourhood (Mofarah et al. 2013).

\section{Colours and Gender}

Men are said to prefer blue and orange more than women who are more attracted to yellow and purple (Babolhavaeji et al. 2015). However, Westland (2015) found that men preferred colder colours like green and purple and women liked the colours red and orange more. Most researches concluded that the colours blue and black were the most favourite colour for both genders (Akcay, 2012; Chang, 2010; Sakamoto, 2013; Nezhad, 2013). Red and black were considered to be masculine colours while pink was seen as more feminine (Zhang, 2015). Men were also said to be more tolerant of grey, white and black while women leaned more towards red and blue (Nezhad, 2013; Singh, 2006). It was found that colours are 
more important for women than for men (Akcay, 2013; Khouw, 2002), although, Ackay's 2012 research showed that men were more interested in colours than women. Increasing age and culture also play a part in colours importance when purchasing of products (Akcay, 2011; Akcay, 2013; Westland; 2015).

\section{Colours and Consumer Behavior}

Consumers are affected by colours in the buying process. When thinking of purchasing gardening products, people associate the colour green to the products. While searching, consumers recall product colours that they have been repetitively exposed to and think of that particular product first. Consumers make their choice to purchase a product based on its price, brand and colour (Page, 2012). Colour was found to not be of great importance for people when they buy a product (Singh, 2006; Kumar, 2007; Sliburyte et al. 2014). However, this statement is contradicted by Akcay (2013) who pointed out that almost $68 \%$ of his respondents gave colour great importance when it comes to purchasing a product.

\section{Buying Process, Gender and Colours}

Colour was noted to be more important to females especially for products like bags and clothing while men gave more importance to colour when it came to products such as beverages and digital cameras. It was also discovered that both genders gave more importance to colour when it came to selfexpressive products such as clothes, backpacks, shoes and so on and that for technological products, such as cell phones and computers, colours were not very stressed upon. Colours were also more important to women than men (Akcay, 2012; Akcay, 2013). Men are more interested in buying sports, electronic, and digital products while women are more prone to focus on purchasing health, laundry, and beauty products $(\mathrm{Hu}, 2004)$. Some gender differences were also noted between men and women in their purchasing behavior. Men are said to be more logical and analytical in their purchases and are motivated by their need to acquire the product at any cost (Banyte, 2015; Castro, 2015; Mitchell, 2014). Abrudan (2016) argued that women are more logical and analytical. Women are also said to be "better shoppers", making a $10 \%$ saving in cost (Dennis, 2004).

\section{Gender Perception of Products}

The product gender classification process starts at a very young age, thus driving a truck is seen as masculine and cooking is seen as feminine (Fodness, 1996; Collins, 1984). Some products, such as toothpaste, are also said to have no gender at all, thus being classified as Androgynous (Fugate \& Phillips, 2010). Products having colours red, blue or orange are more masculine while those having colours like pink, lavender or yellow are more feminine (Auster \& Mansbach, 2012).

\section{Colours and Meanings}

The colour red was associated with "love", blue with "calm" and "masculinity", purple with "spirituality", yellow with "joy", green with "nature", white with "purity", black and brown with "sadness" and "death", and grey with "depression" (Akcay, 2013; Chang, 2010; Singh, 2006; Kaya, 2004; Labrecque, 2012). Black also showed elegance and yellow reminded people of summer (Sliburyte, 2014). Red and yellow were further said to be stimulating colours while green and blue were said to be calming (Mofarah et al. 2013). It is also observed that different cultures associate different colours to different meaning. Yellow is seen as happy in USA but represents death in Mexico (Aslam, 2006).

\section{METHODOLOGY}

An in depth analysis of previous researches were done prior to designing a questionnaire which served as an instrument to answer the objectives and research questions. A survey was carried out among 150 students of the University of Mauritius aged $18-25$ years old to gain their insights about colours.

Using quota sampling, face to face interviews were carried over three days, whereby the same number of males and females participated. The number of respondents was $68 \%$ and $32 \%$ from $18-21$ age group and $22-25$ age groups respectively. $52 \%$ of the respondents were from urban areas while the remaining 
was from rural regions and the results were analyzed by using SPSS version 20 statistical software package. The questionnaire was designed to cover the importance of colours in buying process, favourite colours for different product types and meanings associated with colours. The results were computed in SPSS version 20 and the results were discussed and their implications on marketing were put forward.

The following hypotheses were developed:

Hypothesis 1: The importance attributed to colours in marketing varies by men and women.

Hypothesis 2: Women and men are both interested in colours in marketing but their choice varies across different products.

Hypothesis 3: The use of Colours in marketing and their buying decisions impact will vary on a gender basis.

Hypothesis 4: Women will have a favourite colour as compared to men during purchase decisions.

Hypothesis 5: Colours in marketing have different meanings associated to them on a gender basis.

\section{HYPOTHESES}

\section{General Perceptions of Colours}

Colours impacts our daily life, whether we know it or not (Khouw, 2002; Sliburyte et al. 2014; Singh, 2006; Kerckhove, 2014; Kumar, 2007). It was found that colours are more important for women than for men (Akcay, 2013; Khouw, 2002). However, this was later contradicted and men was also said to be interested in product colours (Akcay, 2012). The first hypothesis developed is depicted below:

Hypothesis 1: The importance attributed to colours by men and women differ from a gendered perspective

$\boldsymbol{H}_{0}:$ Colour is more important for women than for men.

$\boldsymbol{H}_{1}:$ Colour is important for both genders.

\section{Colour and Buying Intentions}

Colour is a determining factor in motivating consumers to purchase a particular product (Singh, 2006; Sliburyte et al. 2014; Kumar, 2007). It was also said that colours are more important for women during the purchase process (Akcay, 2013; Akcay, 2012). Thus, the following hypothesis was developed:

Hypothesis 2: The colour of a product is important for people in the buying process.

$\boldsymbol{H}_{0}$ : Colour is more important for women during purchase of a product.

$\boldsymbol{H}_{2}:$ Colour is important for both genders during the purchase of a product.

\section{Colours and Types of Products}

It was found that the importance attributed to colours was diverse depending on the product type, more specifically, if the product was personal or non-personal. It was discovered that women are more interested in colours if it was for personal products while men are more interested in colours if it was for non-personal products (Akcay, 2011; Akcay, 2013; Akcay, 2012). It is therefore posited that:

Hypothesis 3: Women and men are interested in colours across different products types

$\boldsymbol{H}_{0}$ : Personal products' colours are more important for women while non-personal colours are more important for men.

$\boldsymbol{H}_{3}$ : The types of products will not impact on their colours' importance by men and women.

72 Journal of Marketing Development and Competitiveness Vol. 13(3) 2019 


\section{Favorite Colours}

Previous findings found out that women were more likely to have favourite colours compared to men (Akcay, 2012; Akcay, 2013; Westland; 2015). The colour blue was also found to be very popular among both genders (Westland, 2015; Nezhad, 2013; Akcay, 2012; Sakamoto, 2013). Another favourite colour by both genders was black (Akcay, 2012; Sakamoto, 2013). The colour orange was the least preferred by men and women (Nezhad, 2013). The fourth hypothesis developed reads as follows:

Hypothesis 4: Women will have a favourite colour as compared to men.

$\boldsymbol{H}_{0}:$ Women are more likely to have a favourite colour as compared to men.

$\boldsymbol{H}_{4}:$ Both women and men are likely to have a favourite colour.

\section{Colours and Meanings}

It was found that people attributed different meanings to different colours, independent of their genders (Sliburyte, 2014; Chang, 2010; Kaya, 2004; Labrecque, 2012). The colour red was associated with "love", blue with "calm" and "masculinity", purple with "spirituality", yellow with "joy", green with "nature", white with "purity", black and brown with "sadness" and "death", and grey with "depressing" (Akcay, 2013; Chang, 2010; Singh, 2006; Kaya, 2004).

Hypothesis 5: Colours have meanings associated to them.

$\boldsymbol{H}_{0}:$ Men and women do not associate different meanings to different colours.

$\boldsymbol{H}_{5}:$ Men and women associate different meanings to different colours.

\section{EMPIRICAL FINDINGS}

\section{Demographic Results}

FIGURE 1

GENDER OF RESPONDENTS

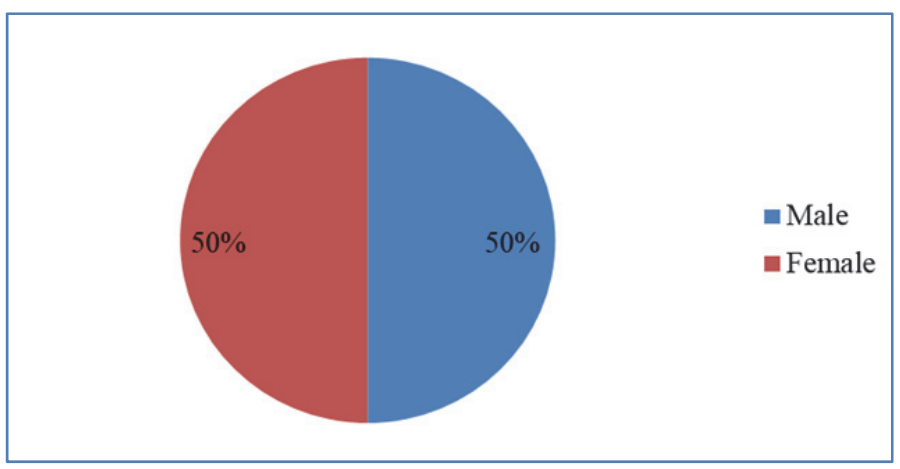

The sample was based on quota sampling and the number of males to females was equal. Thus, $50 \%$ of the sample was men and 50\% was women. 
FIGURE 2

AGE OF RESPONDENTS

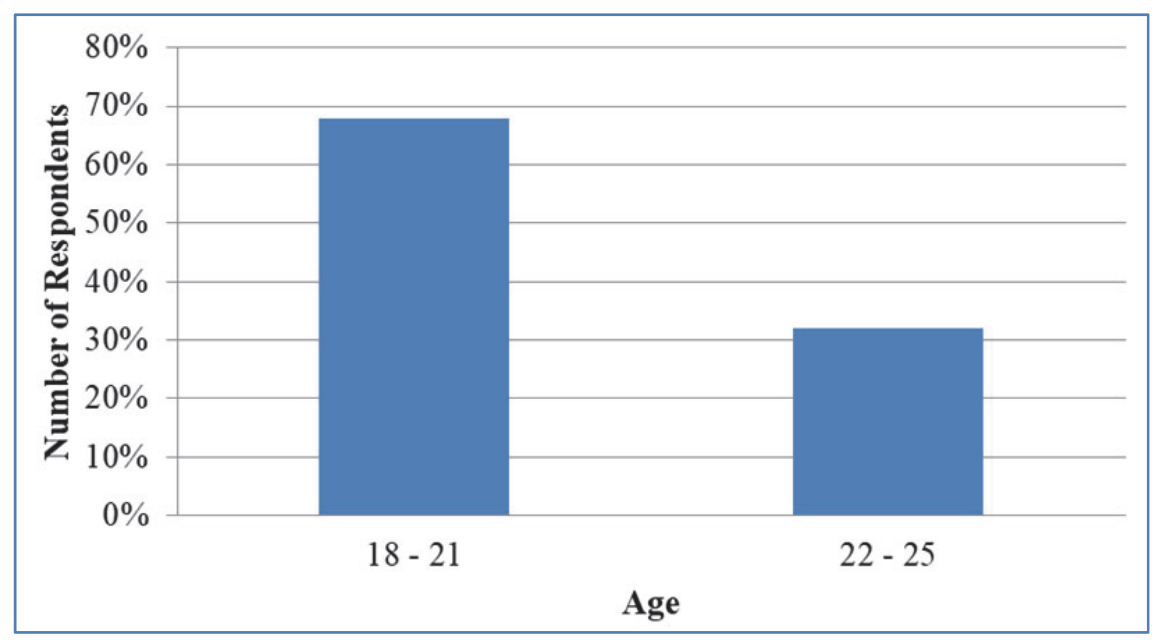

The number of respondents was $68 \%$ and $32 \%$ from $18-21$ age groups and $22-25$ age groups respectively. The total number of respondents was 150 .

FIGURE 3

RESIDING REGIONS OF RESPONDENTS

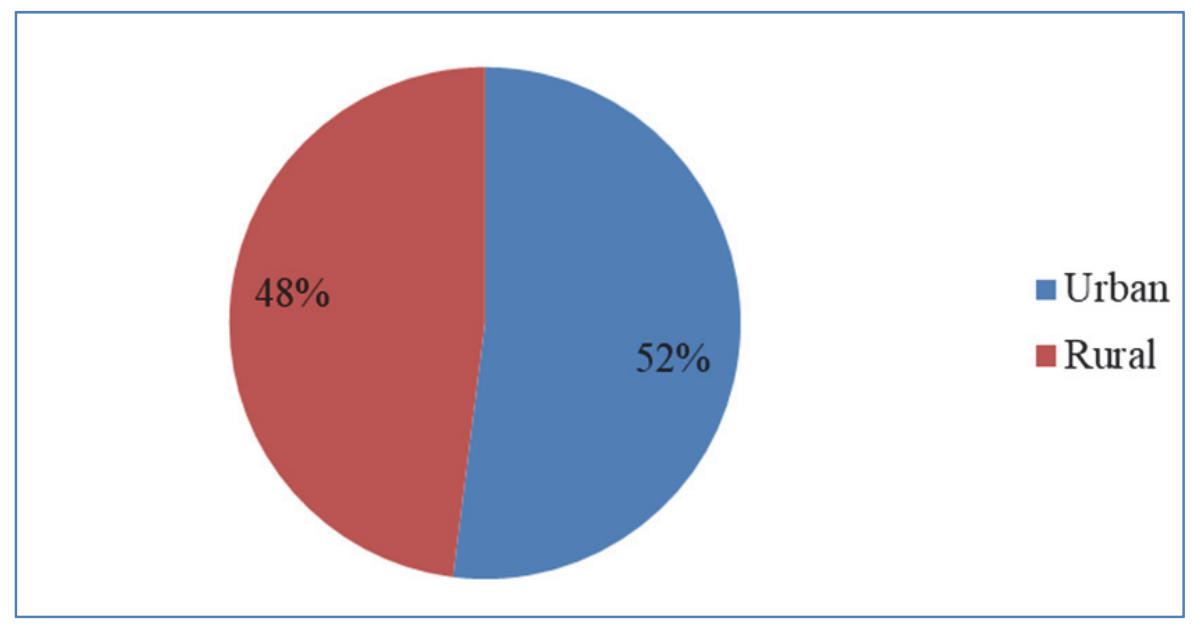

$52 \%$ of the respondents were from urban areas while the remaining $48 \%$ were from rural regions. All the respondents are students.

Respondents were provided a list of statements about colour and asked to which degree they agreed upon each statement. From Table 4.1, it can be concluded that both men and women attribute importance to colours. Both men and women attributed importance to product colours $(p=0.042)$, agreed that colours help them identify a product $(\mathrm{p}=0.105)$, confirmed that colours encourage repeat purchases $(\mathrm{p}=0.638)$, are loyal to products due to their colours $(p=0.506)$, are attracted to both warmer $(p=0.947)$ and colder $(p=0.789)$ colours, and said that colours help them recall a particular product $(p=0.311)$.

\section{Choice of Favourite Colours from a Gender Perspective}

The respondents were also asked to choose their favorite colours for different products that were given to them. The results are depicted in Figure 4.4 and Figure 4.5. From Figure 4.4, it can be observed 
that the most preferred colours by both men and women for personal products are Black. Blue and White are also popular colours, especially for clothes. Colours such as Orange, Yellow, Red, Green and Purple were less favoured. White and Grey were also stand outs for both genders.

Clothes: mostly preferred for the colour Red, Blue, Yellow, Green, Purple, White, Grey and Orange.

Mobile phones: Black, White, and Grey were more popular.

Bags: popular among the colours Blue, Yellow, Green, Brown, Black, Purple, White, Grey and Orange.

Watches: colours Blue, Green, Brown, Black, Purple, White, and Grey were mostly preferred.

Shoes: were associated with the colours Red, Blue, Brown, Black, White, and Grey.

The most popular colours across the different products were Black, Blue, Grey, White, and Brown. The products mostly interested for their colours are clothes $(33.8 \%)$, shoes $(27.4 \%)$, bags $(26.9 \%)$, watches $(21.4 \%)$ and mobile phones (17.3\%).

From Figure 4.5, the same patterns can be observed with Black being the most preferred colour for non-personal products. Blue was also put forward as the second favourite and the other colours were not well liked by men and women. The colour Orange was again the least liked by both genders. The colours White and Grey were well liked by men and women while Brown, Yellow, Green, Purple and Red were not popular.

Toothbrush: more popular among colours Red, Blue, Yellow, Green, Purple, and Orange. Cooking appliances: were chosen among colours like Brown, Black, White and Grey. Computer: colours Black, White and Grey were mostly preferred.

Umbrellas: colours Blue, Yellow, Brown, Black, Purple, and Orange were more famous. Television: colours Black, White and Grey were mostly chosen by the respondents.

Thus, it can be concluded that the colour Black is mostly preferred by both genders for a lot of the different products, be it personal or non - personal products. The products mostly interested for their colours are toothbrush (24.4\%), umbrellas (23.9\%), cooking appliances $(18.7 \%)$, computer $(17.9 \%)$ and television $(14.1 \%)$.

FIGURE 4

IMPORTANCE OF COLOURS FOR PERSONAL PRODUCTS

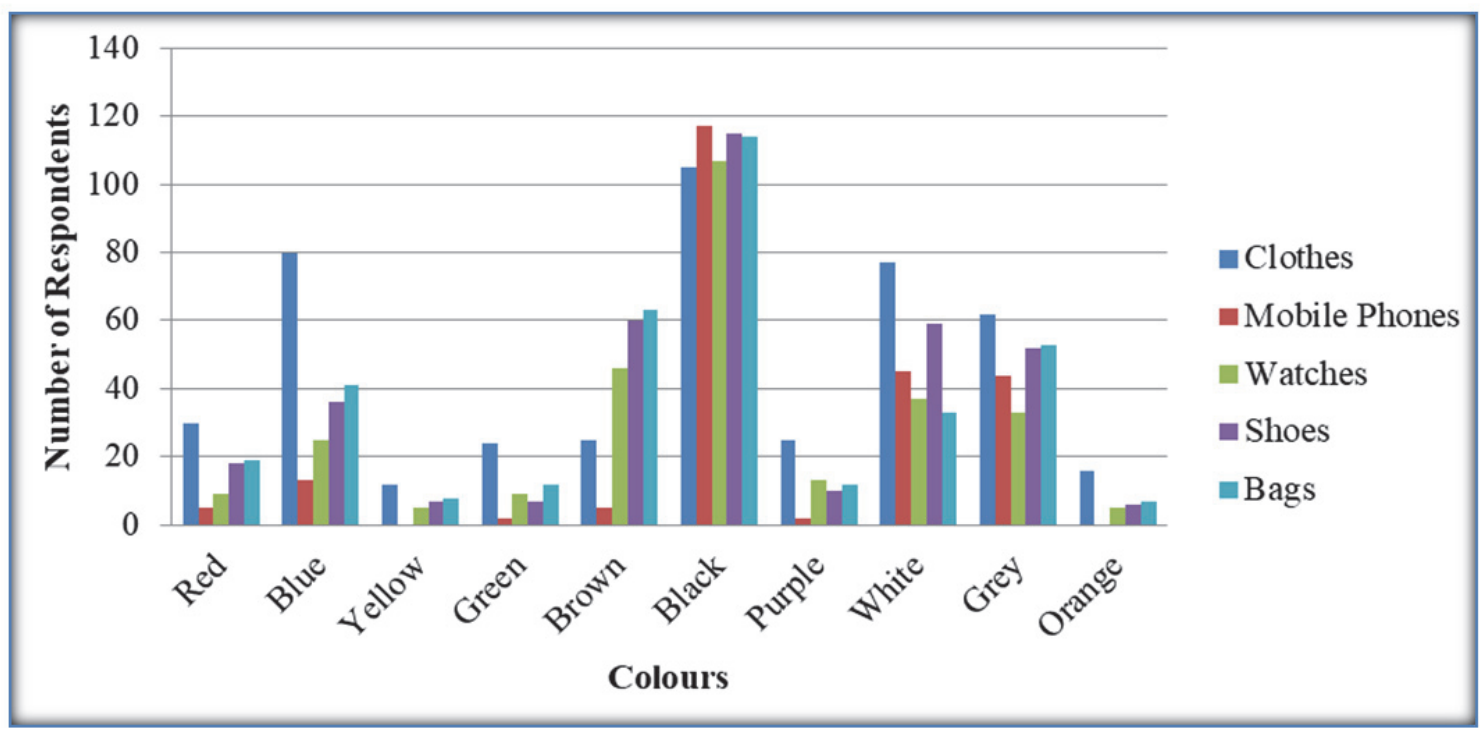


FIGURE 5

IMPORTANCE OF COLOURS FOR NON-PERSONAL PRODUCTS

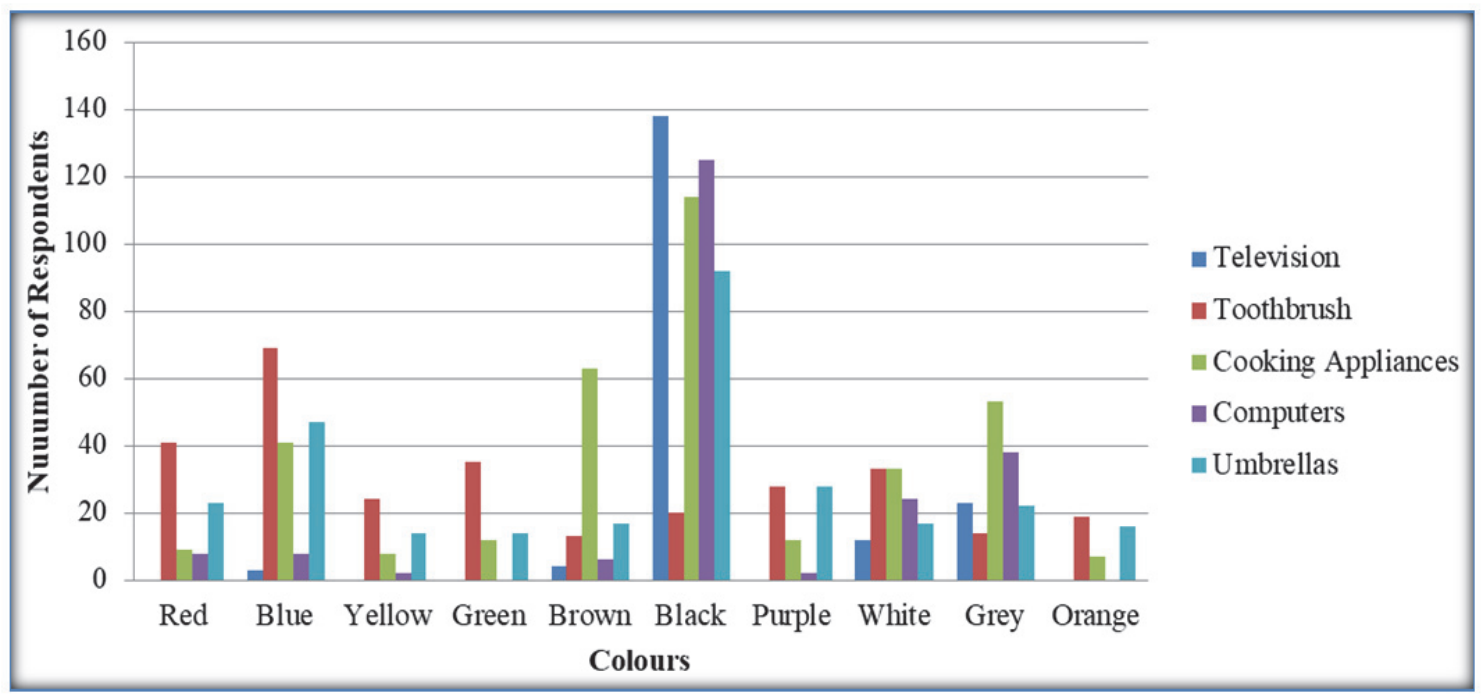

93.3\% of the respondents agreed that colours did have meanings associated to them. Furthermore, the different meanings associated with the colours can be viewed from Figure 4.6. It was found out that "love", "femininity", "warmth" and "joy" were associated with Red, "masculinity", "unhappiness" and "death" with Black, "nature" with Green, "cleanness", "spirituality", "conservative", "calm" and "trust" with White.

FIGURE 6

\section{COLOURS AND MEANINGS}

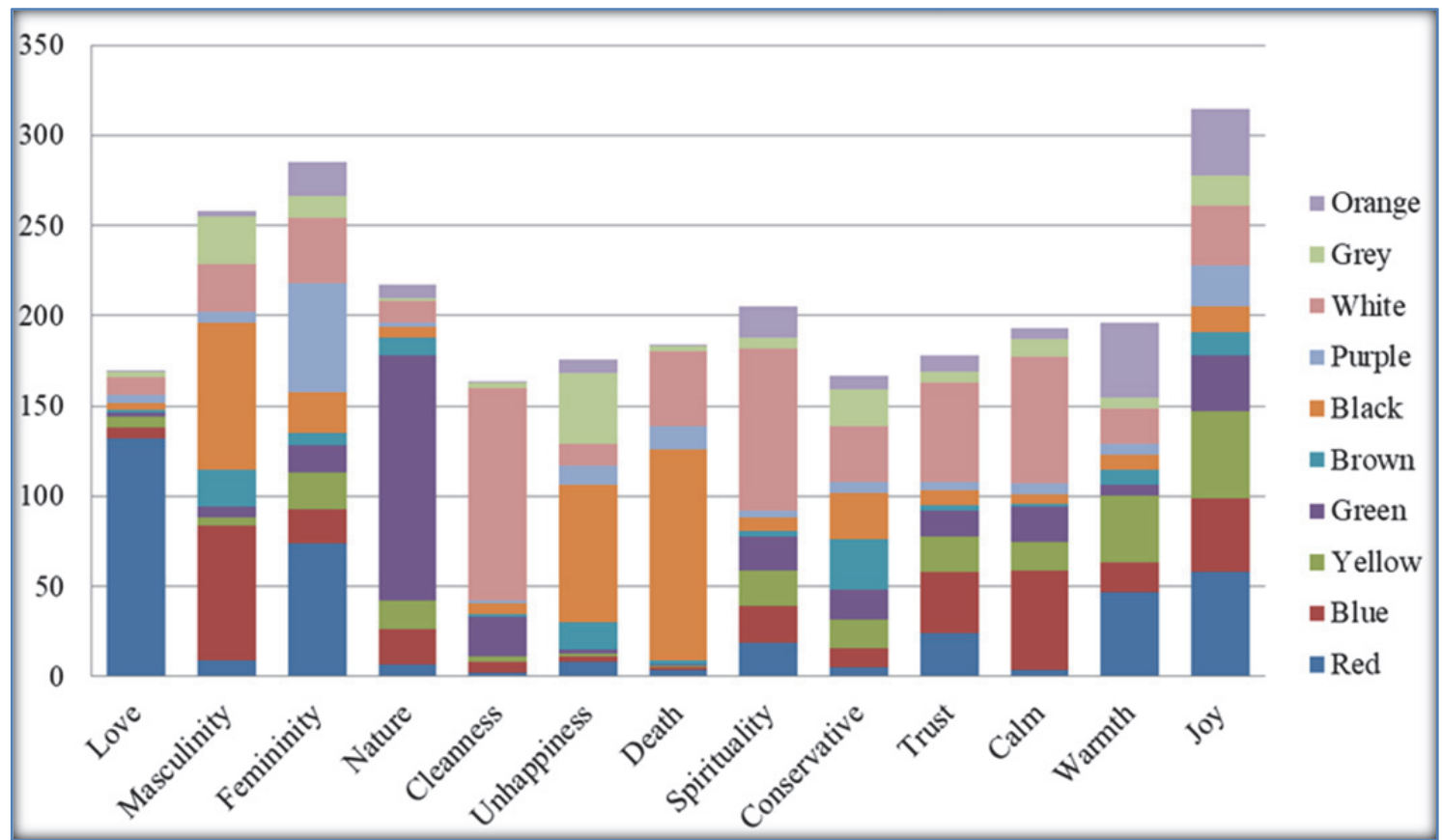


Men were noted to be more interested in colours. It was found that women are also interested in technological products' colours. These results showed that the most preferred colours were Blue and Black. It was discovered that colours have different meanings associated with them. The colours Red, Black and White were mostly associated with different meanings.

\section{HYPOTHESES TESTING}

\section{Hypothesis 1}

$\mathrm{H}_{0}$ : Colour is more important for women than for men.

$\mathrm{H}_{1}$ : Colour is important for both genders.

From Table 4.1, it can be seen that both men and women attribute importance to colours, although there are some differences. The first statement has a $p$ value of 0.042 thus there is a very small difference between men and women when it comes to the importance of colour for a product. Descriptive test was performed and it was observed that men attributed more importance to colour for product (men, $\mathrm{M}=2.43$, women, $\mathrm{M}=1.97$ ). The second statement has a $\mathrm{p}$ value of 0.105 which indicate that there is no significant difference in the way that colour helps men and women identify a product easily (men, $\mathrm{M}=2.32$, women, $M=1.97)$. The next statement has a $p$ value of 0.033 which shows that there is a significant difference between men and women when it comes to colour having the ability to change their mood (men, $\mathrm{M}=$ 2.49 , women, $\mathrm{M}=2.07$ ). The fourth statement has a $\mathrm{p}$ value of 0.638 which shows that there is no significant difference between men and women when it comes to buying a product again because of its colour (men, $\mathrm{M}=2.37$, women, $\mathrm{M}=2.45$ ).

The fifth statement was about being loyal to a product due to the latter's colour has a $\mathrm{p}$ value of 0.506 . This shows that there is no significant difference among men and women (men, $M=2.75$, women, $\mathrm{M}=2.63$ ). The attraction to warmer colours was quite similar for both genders with a $\mathrm{p}$ value of 0.947 , indicating that there is no difference between men and women (men, $\mathrm{M}=2.47$, women, $\mathrm{M}=2.45$ ). Likewise, there was no difference observed to the attraction to colder colours with a $\mathrm{p}$ value of 0.789 (men, $\mathrm{M}=2.41$, women, $\mathrm{M}=2.37$ ). Finally, the last statement about colour helping to recall a particular product has a $\mathrm{p}$ value of 0.311 , meaning that there is a no significant difference between men and women (men, $\mathrm{M}=2.15$, women, $\mathrm{M}=1.93$ ). From these results, it can be concluded that both men and women attribute importance to colours. The $\mathrm{p}$ values also indicate that some statements did not have much significant differences between both groups. Based on these findings, $\mathrm{H}_{1}$ is accepted while $\mathrm{H}_{0}$ is rejected.

\section{Hypothesis 2}

$\mathrm{H}_{0}$ : Colour is more important for women during purchase of a product.

$\mathrm{H}_{2}$ : Colour is important for both genders during the purchase of a product.

$82.7 \%$ of females answered positively that colours are important when they purchase a product while $66.7 \%$ of males agreed to that same statement. Levene's Test for Equality of Variances (independent sample t-test) was used to analyse. As seen from Tables 4.1 and 4.2 respectively differences in the importance given to the colours when purchasing products.

There was a significant difference between men and women concerning their personal colour preference and their purchasing of products $(\mathrm{p}=0.006)$. Descriptive analysis of the means shows that personal colour preference affects more women than men (men, $M=3.36$, female, $M=3.79$ ). There was no significant difference observed between men and women for the extent to which colour is important during the purchasing of a product with $\mathrm{p}=0.855$. This is further confirmed with the means obtained for both group (men, $\mathrm{M}=3.03$, women, $\mathrm{M}=3.00$ ). 
TABLE 1

IMPORTANCE OF COLOURS BASED ON GENDER PERSPECTIVES

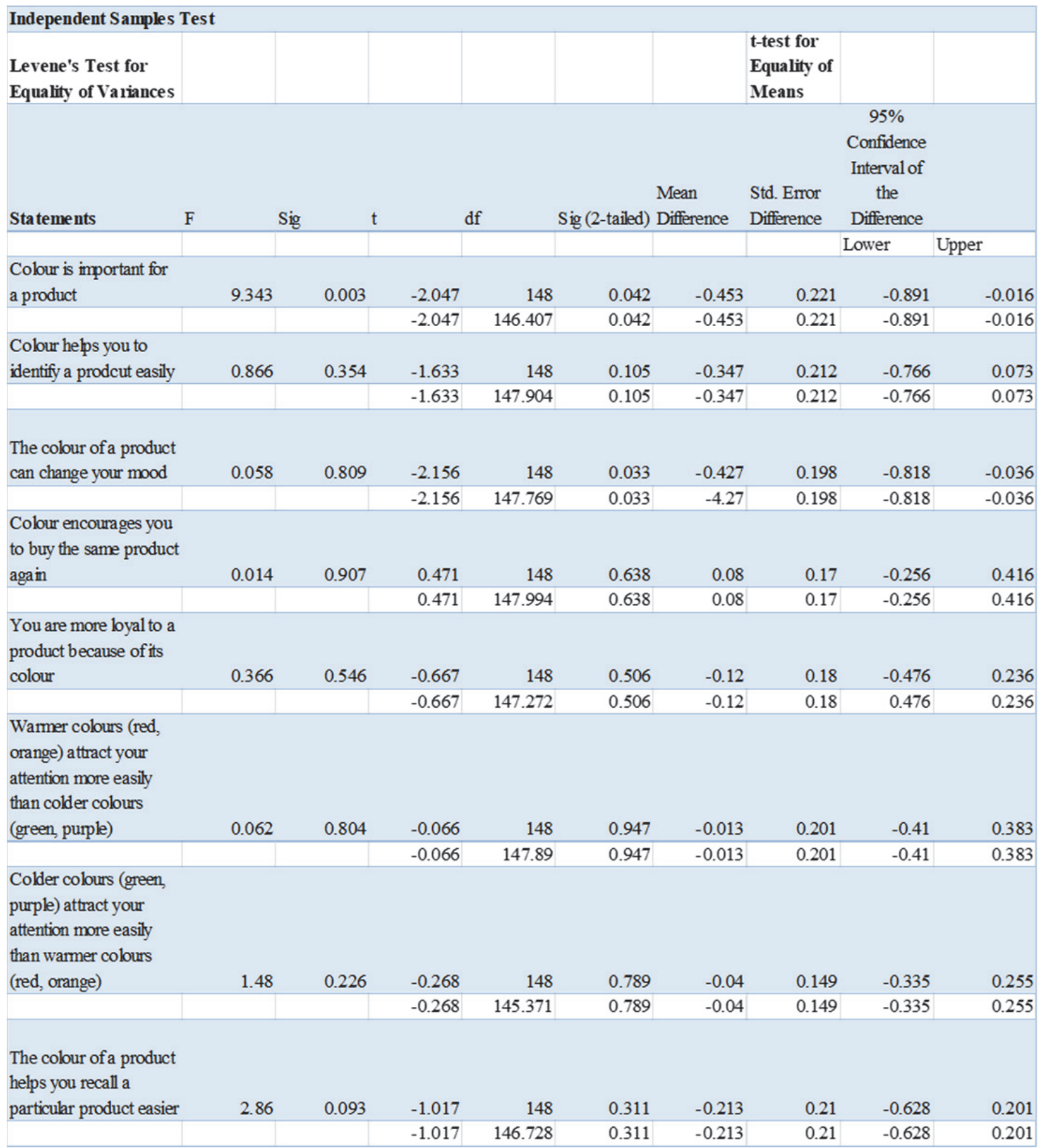

Based on these findings, it can be concluded that colour is important for both genders and does play a role in their buying process. Thus, $\mathrm{H} 0$ is rejected in favour for $\mathrm{H} 2$. 
TABLE 2

IMPORTANCE OF COLOURS DURING BUYING OF PRODUCT

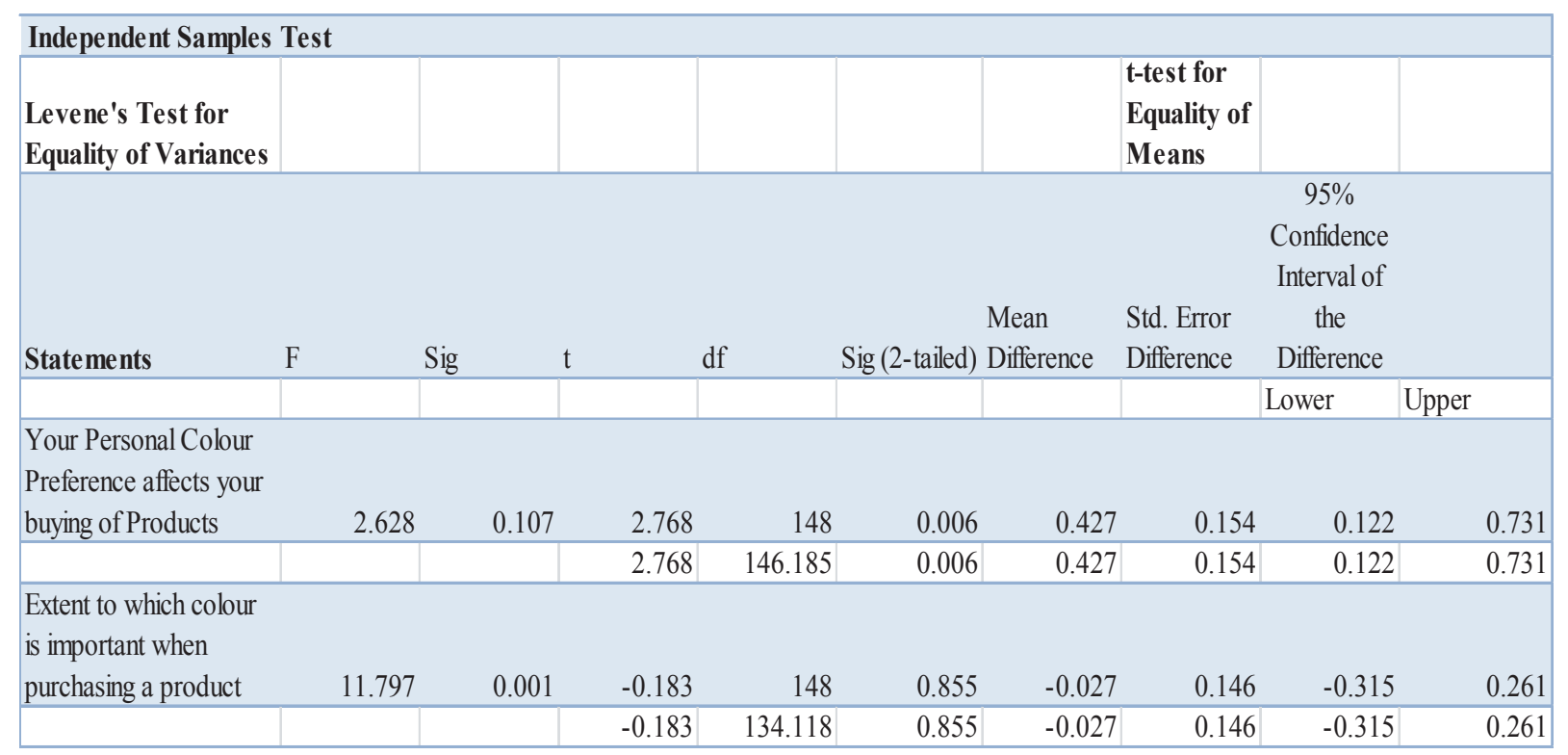

\section{Hypothesis 3}

$\mathrm{H}_{0}$ : Personal products' colours are more important for women while non-personal colours are more important for men.

$\mathrm{H}_{3}$ : The types of products will not impact on their colours' importance by men and women.

A list of products that the respondents are familiar with were presented to them. They were then asked to rate the level of importance they attribute to each of the products when they purchase them. The list consisted of 5 personal products (clothes, bags, watches, shoes, mobile phones) and 5 non-personal products (television, toothbrush, umbrellas, computer, cooking appliances). Here, personal products means products that directly represent the person's personality and non-personal products means products that are technological and which do not reflect a person's personality. An independent sample t-test was used to know the difference between men and women in the preference they attributed to the specific products and the results were compiled in Table 4.3.

There were no significant differences in almost all of the products, more specifically bags $(p=0.326)$, clothes $(p=0.78)$, television $(p=0.665)$, shoes $(p=0.841)$, watches $(p=0.053)$, toothbrush $(p=0.173)$, computer $(\mathrm{p}=0.337)$, and cooking appliances $(\mathrm{p}=0.244)$. The other products did show some significant differences in colour preference during the buying process (umbrellas, $\mathrm{p}=0.020$; mobile phones, $\mathrm{p}=$ 0.042). To further differentiate between men and women and which products each of the gender gave more importance to when it came to colours, descriptive statistics were used to find the means the results are found in Figure 4.7. The figure shows that women were influenced by colours for products such as clothes, bags, television, watches, shoes, computer and mobile phones On the other hand, for men, colours were more important for products such as toothbrush, umbrella and cooking appliances. Thus, $\mathrm{H}_{0}$ is rejected and $\mathrm{H}_{3}$ is accepted. 
TABLE 3

COLOUR PREFERENCE OF DIFFERENT TYPES OF PRODUCTS

\begin{tabular}{|c|c|c|c|c|c|c|c|c|c|}
\hline \multicolumn{10}{|c|}{ Independent Samples Test } \\
\hline Levene's & & & & & & & \multirow{3}{*}{\multicolumn{2}{|c|}{$\begin{array}{l}\text { t-test for } \\
\text { Equality of } \\
\text { Means }\end{array}$}} & \\
\hline Test for & & & & & & & & & \\
\hline \multirow[t]{5}{*}{ Equality of } & & & & & & & & & \\
\hline & & & & & & & \multicolumn{3}{|c|}{$95 \%$} \\
\hline & & & & & & & & onfidence & \\
\hline & & & & & & & & terval of & \\
\hline & & & & & & Mean & Std. Error & the & \\
\hline \multirow[t]{2}{*}{ Products } & $\mathrm{F}$ & $\mathrm{Sig}$ & t & df & $\operatorname{Sig}$ (2-tailed) & Difference & Difference & ifference & \\
\hline & & & & & & & & wer & Upper \\
\hline \multirow[t]{2}{*}{ Clothes } & 4.648 & 0.033 & 1.778 & 148 & 0.078 & 0.373 & 0.21 & -0.042 & 0.788 \\
\hline & & & 1.778 & 146.349 & 0.078 & 0.373 & 0.21 & -0.042 & 0.788 \\
\hline \multirow[t]{2}{*}{ Bags } & 0.784 & 0.377 & 0.985 & 148 & 0.326 & 0.28 & 0.284 & -0.282 & 0.842 \\
\hline & & & 0.985 & 147.832 & 0.326 & 0.28 & 0.284 & -0.282 & 0.842 \\
\hline \multirow[t]{2}{*}{ Television } & 0.483 & 0.488 & 0.434 & 148 & 0.665 & 0.067 & 0.154 & -0.237 & 0.37 \\
\hline & & & 0.434 & 147.911 & 0.665 & 0.067 & 0.154 & -0.237 & 0.37 \\
\hline \multirow[t]{2}{*}{ Watches } & 3.327 & 0.07 & 1.949 & 148 & 0.053 & 0.48 & 0.246 & -0.007 & 0.967 \\
\hline & & & 1.949 & 147.252 & 0.053 & 0.48 & 0.246 & -0.007 & 0.967 \\
\hline \multirow[t]{2}{*}{ Shoes } & 0.031 & 0.861 & 0.201 & 148 & 0.841 & 0.04 & 0.199 & -0.354 & 0.434 \\
\hline & & & 0.201 & 147.996 & 0.841 & 0.04 & 0.199 & -0.354 & 0.434 \\
\hline \multirow[t]{2}{*}{ Toothbrush } & 0.409 & 0.524 & -1.369 & 148 & 0.173 & -0.187 & 0.136 & -0.456 & -0.083 \\
\hline & & & -1.369 & 147.94 & 0.173 & -0.187 & 0.136 & 0.456 & -0.083 \\
\hline \multirow[t]{2}{*}{ Umbrella } & 0.078 & 0.78 & -2.359 & 148 & 0.02 & -0.413 & 0.175 & -0.76 & -0.067 \\
\hline & & & -0.2359 & 147.746 & 0.02 & -0.413 & 0.175 & -0.76 & -0.067 \\
\hline \multirow[t]{2}{*}{ Computer } & 12.189 & 0.001 & 0.963 & 148 & 0.337 & 0.16 & 0.166 & -0.168 & 0.488 \\
\hline & & & 0.963 & 137.926 & 0.337 & 0.16 & 0.166 & -0.169 & 0.489 \\
\hline \multicolumn{10}{|l|}{ Mobile } \\
\hline \multirow[t]{2}{*}{ Phones } & 0.009 & 0.923 & 2.047 & 148 & 0.042 & 0.52 & 0.254 & 0.018 & 1.022 \\
\hline & & & 2.047 & 147.853 & 0.042 & 0.52 & 0.254 & 0.018 & 1.022 \\
\hline \multicolumn{10}{|l|}{ Cooking } \\
\hline \multirow[t]{2}{*}{ Appliances } & 0.076 & 0.0784 & -1.17 & 148 & 0.244 & -0.173 & 0.148 & -0.466 & 0.119 \\
\hline & & & -1.17 & 146.103 & 0.244 & -1.73 & 0.148 & -0.466 & 0.119 \\
\hline
\end{tabular}


FIGURE 7

IMPORTANCE OF COLOURS TO PRODUCTS TYPES

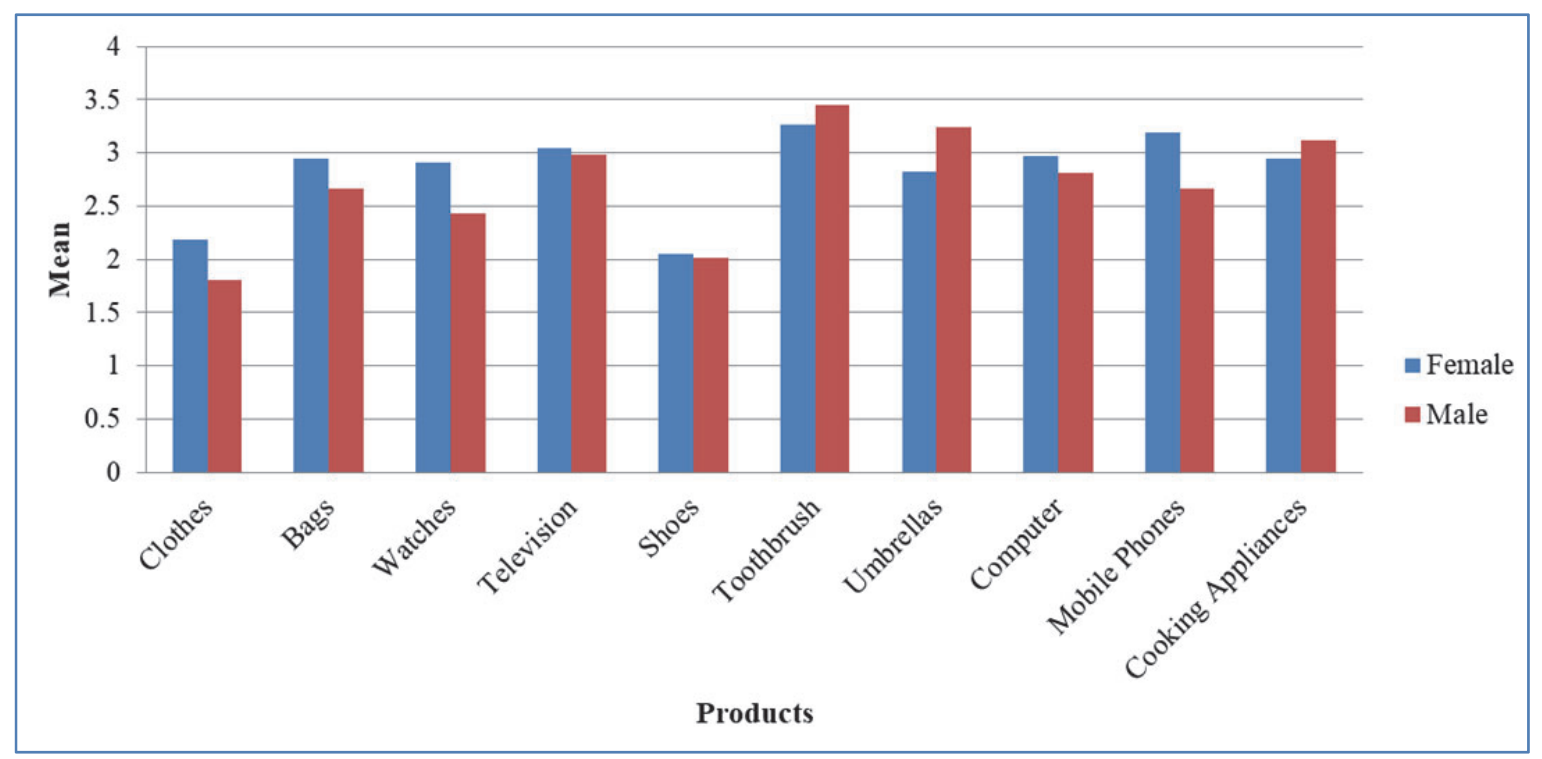

\section{Hypothesis 4}

$\mathrm{H}_{0}$ : Both women and men are likely to have a favorite colour.

$\mathrm{H}_{4}$ : Women are more likely to have a favorite colour as compared to men.

$100 \%$ of women answered that they have a favourite colour and $98.7 \%$ of men answered the same. Thus, both genders do have a favourite colour. A Levene's test was performed, whereby the value of $p$ obtained was 0.321 , meaning there is no significant difference between men and women having a favourite colour. From the following findings, we can accept $\mathrm{H}_{0}$ and reject $\mathrm{H}_{4}$. Moreover, from Figure 4.5 , it was found out that the most preferred colour for both men and women was Blue (70.7\%), followed by Black (54.7\%). The least preferred colours were Orange $(11.3 \%)$ and Brown (14\%). White (43.3\%) was also a favourite over Red (28.7\%), Yellow (14.7\%), Green (22.7\%), Purple (24\%) and Grey (38.7\%). A Chi Square test was performed to test whether having a favorite colour depends on the gender of a person. The results can be observed in Table 4.4 whereby it was found that having a favourite colour does not depend on the gender of a person with a Significant P-Value of 0.316. 
TABLE 4

COLOURS AND ITS ASSOCIATION TO GENDER

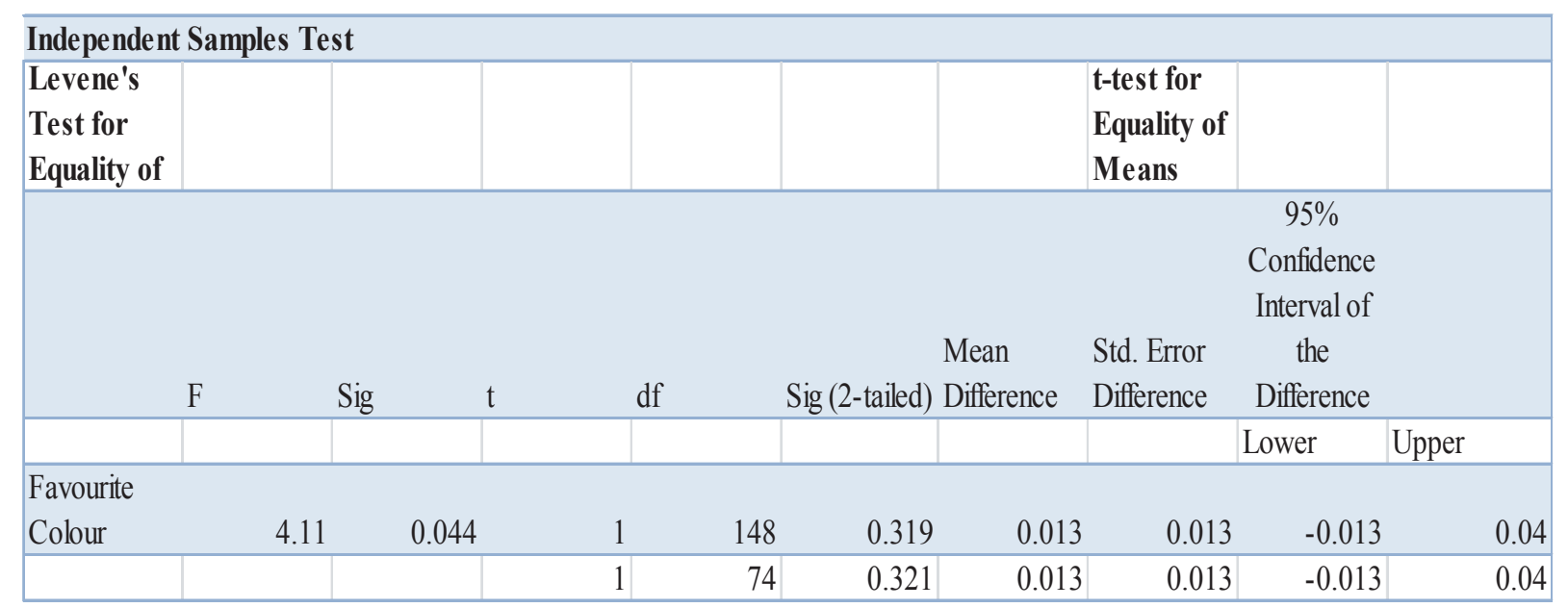

The respondents were also asked to choose their favorite colours for the different products that were given to them. The results are depicted in Figure 4.8 and Figure 4.9.The results were classified into personal and non-personal products so that they were easier to read. From Figure 4.8, it can be found out that the most preferred colours by both men and women for personal products is mainly Black. Blue and White are also popular colours, especially for clothes. Colours such as Orange, Yellow, Red, Green and Purple were less favoured. White and Grey were also stand outs for both genders. Clothes were mostly preferred for the colour Red, Blue, Yellow, Green, Purple, White, Grey and Orange. Mobile phones coloured Black, White, and Grey were more popular. Bags were also popular among a lot of the colours, namely, Blue, Yellow, Green, Brown, Black, Purple, White, Grey and Orange. Watches of colour Blue, Green, Brown, Black, Purple, White, and Grey were mostly preferred. Finally, shoes were associated with the colours Red, Blue, Brown, Black, White, and Grey more. The most popular colours across the different products were Black, Blue, Grey, White, and Brown. The products mostly interested for their colours are clothes (33.8\%), shoes (27.4\%), bags (26.9\%), watches (21.4\%) and mobile phones (17.3\%). 
FIGURE 8

COLOUR PREFERENCE FOR PERSONAL PRODUCTS

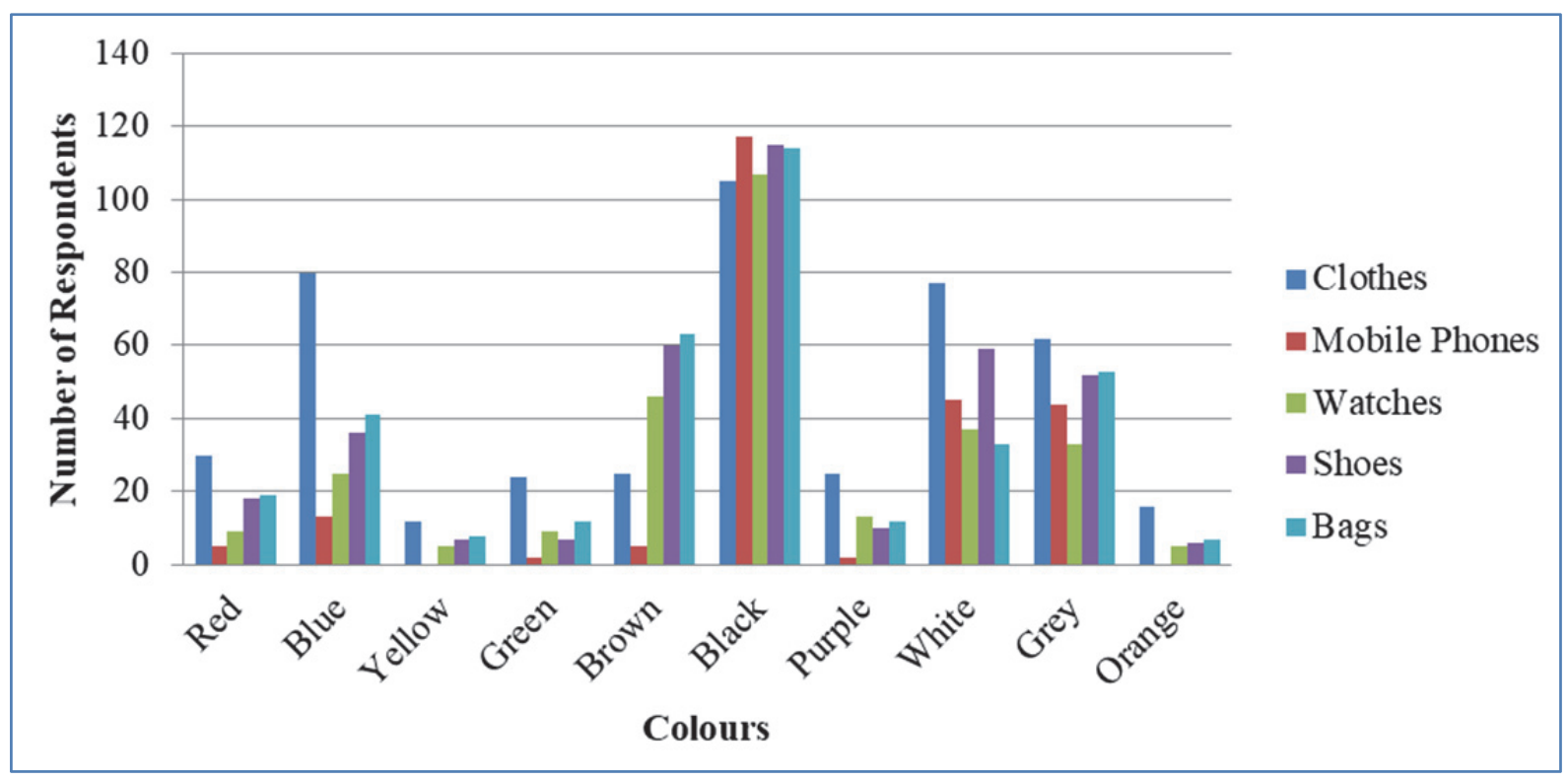

From Figure 4.9, the same pattern can be observed with Black being the most preferred colour for non-personal products. Blue was also put forward as the second favourite and the other colours were not well liked by men and women. The colour Orange was again the least liked by both genders. The colours White and Grey were well liked by men and women while Brown, Yellow, Green, Purple and Red were not popular. Toothbrush was more popular among colours Red, Blue, Yellow, Green, Purple, and Orange. Cooking appliances were chosen among colours like Brown, Black, White and Grey. Computer of colours Black, White and Grey were mostly preferred. Umbrellas of colours Blue, Yellow, Brown, Black, Purple, and Orange were more famous and television of colours Black, White and Grey were mostly chosen by the respondents. The same pattern can be observed from the personal products' colours with the colours Black, White and Grey being the most popular among most products. Thus, it can be concluded that the colour Black is mostly preferred by both genders for a lot of the different products, be it personal or non personal products. The products mostly interested for their colours are toothbrush $(24.4 \%)$, umbrellas (23.9\%), cooking appliances (18.7\%), computer (17.9\%) and television (14.1\%). 
FIGURE 9

\section{COLOUR PREFERENCE FOR NON-PERSONAL PRODUCTS}

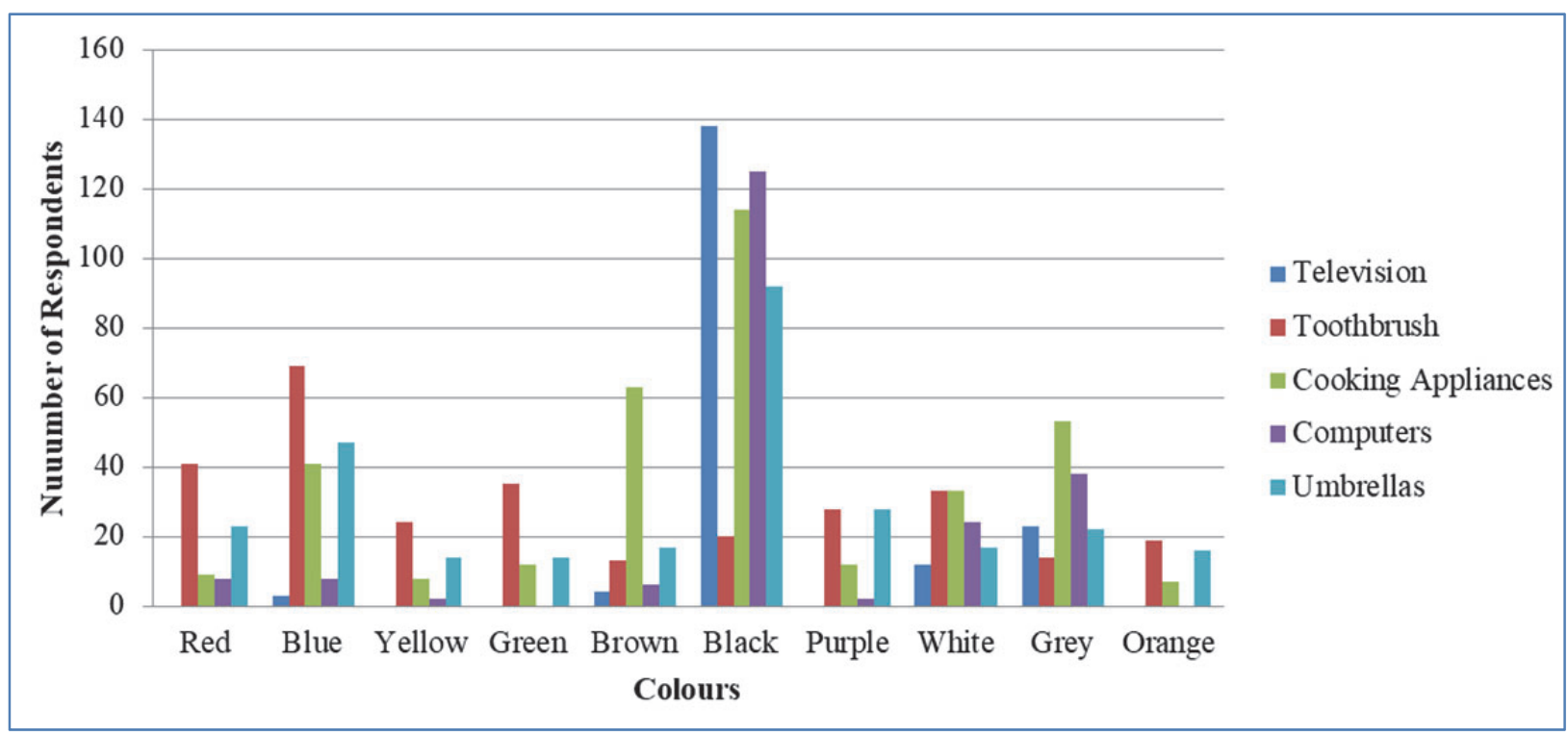

\section{Hypothesis 5}

$\mathrm{H}_{0}$ : Men and women associate different meanings to different colours.

$\mathrm{H}_{5}$ : Men and women do not associate different meanings to different colours.

An independent t-test was carried out and a p value of 0.516 was obtained. This concludes that there is no significant difference in the way that men and women think about colours and the latters' having different meanings. $93.3 \%$ of the respondents agreed that colours did have meanings associated to them. Thus, from these findings, we can accept $\mathrm{H}_{0}$ and reject $\mathrm{H}_{5}$. Furthermore, the different meanings associated with the colours can be viewed from Figure 4.10. It was found out that "love", "femininity", "warmth" and "joy" was associated with Red, "masculinity", "unhappiness" and "death" with Black, "nature" with Green, "cleanness", "spirituality", "conservative", "calm" and "trust" with White. 
TABLE 5

COLOURS AND MEANINGS

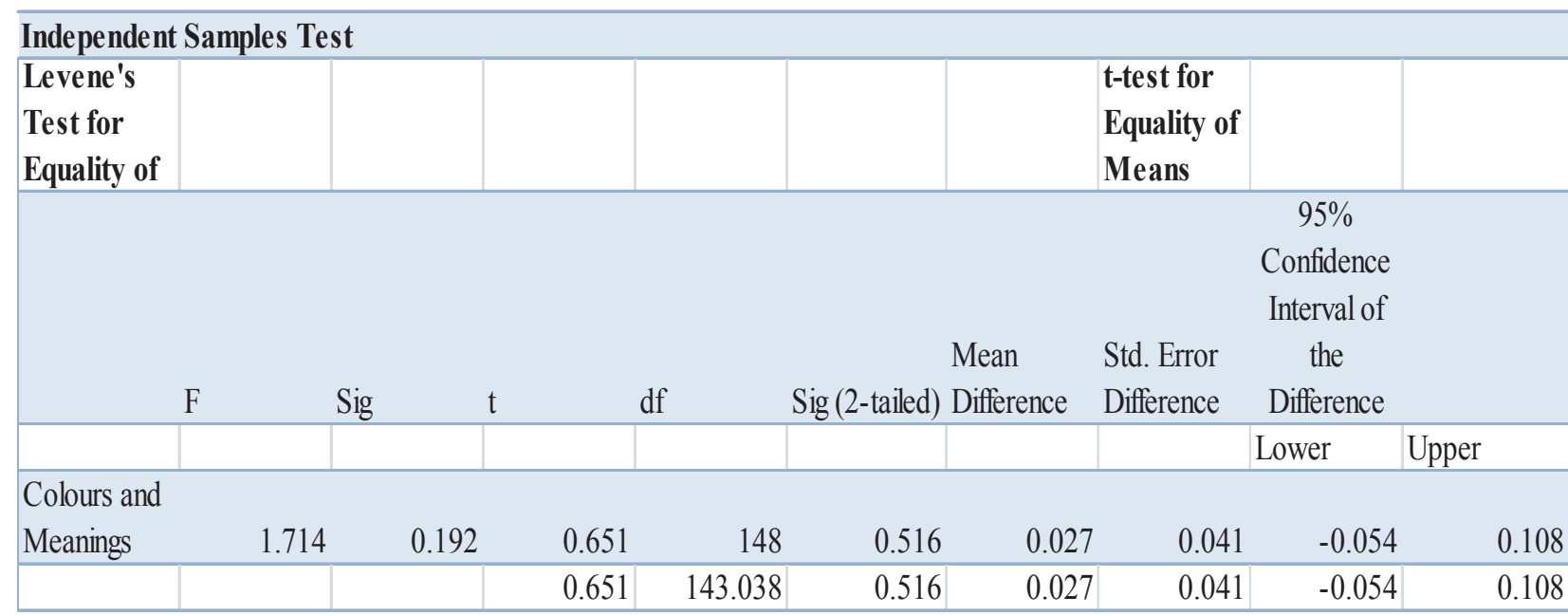

FIGURE 10

COLOURS AND THE DIFFERENT MEANINGS ASSOCIATED

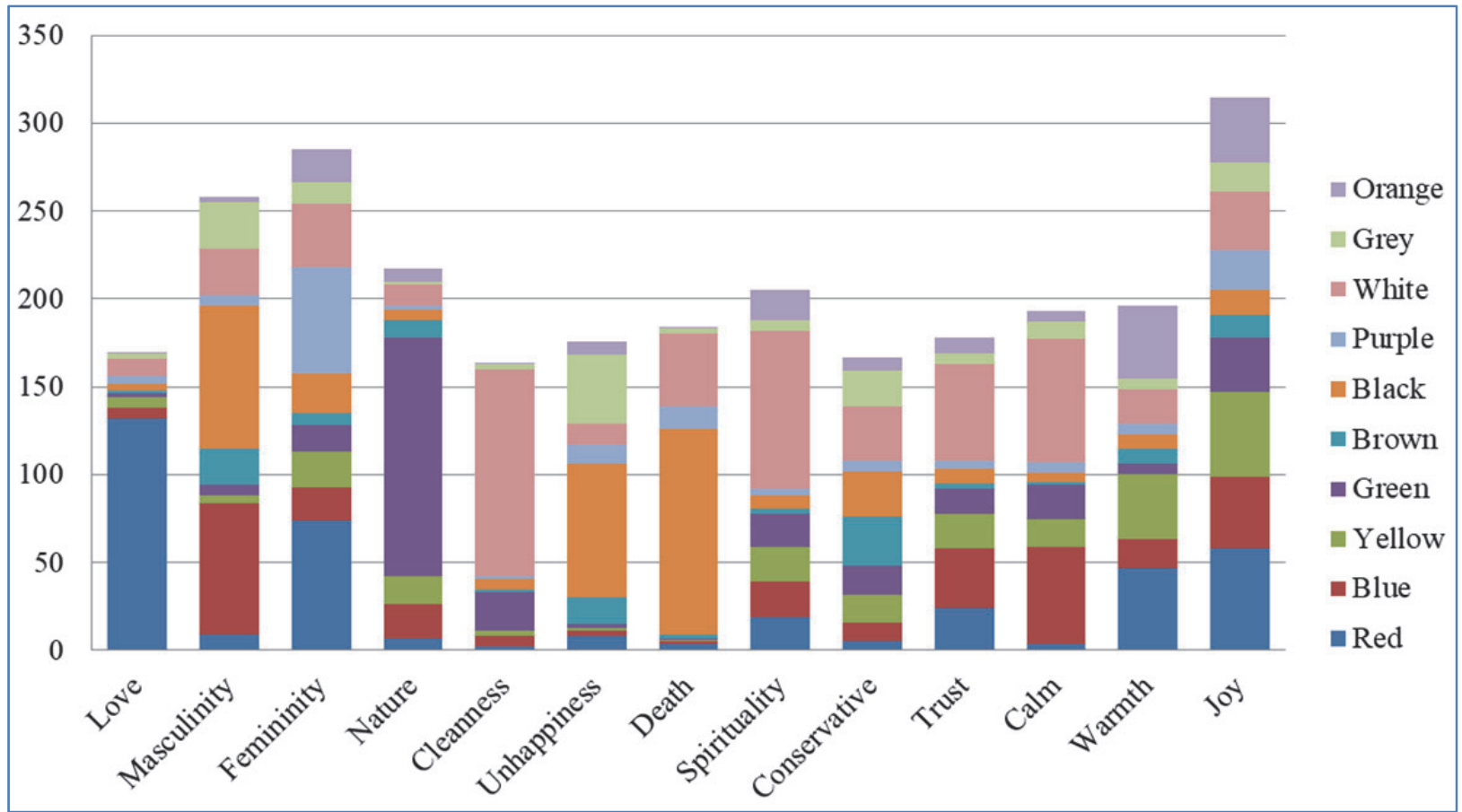

\section{MANAGERIAL IMPLICATIONS OF THE STUDY}

It was found that colours were more important to men compared to women since men agreed more on the statements about colours, such as colour being important for a product, colour helping them to identify a product, colour capable of changing their moods, and colour helping to remember a particular product, which is contradictory of what most previous studies have found out. Although, Akcay (2013) did conclude that men were more interested in colours. It was also found out that both men and women agreed on the fact that colours are important during buying of a product with $82.7 \%$ of women and $66.7 \%$ 
of men answering positively to the question. However, it was noted that women are more affected by their favourite colour while doing purchases more than men. Men also agreed on the fact that colours help them to identify a product, colours can change their mood, colours encourage them to buy the same product again, and colours help them to recall a particular product. Men also said that they are attracted to both warm colours (red, orange) and cold colours (green, purple). These colours can be used in advertisements or in packaging or on billboards or may even be the company logo and so on. These colours will attract the attention of the men and women as well. Women are also interested in colours and marketers need to continue to use colours in their attempt to sell their products or services to both genders.

It was also noted that women are more affected by their personal colour preference when shopping. This raises the need for understanding and knowing your customer. As observed from the results, women give more importance to colour when it comes to products such as clothing, bags, watches, television, shoes, computer and mobile phones. On the other hand, men give more importance to colours when it comes to products such as toothbrush, umbrellas and cooking appliances. Thus, it can be concluded that females give more importance to colours when they do their shopping, especially to products that are personal and reflect their own personalities. Men did score higher means compared to women when it concerned products such as toothbrush, umbrellas and cooking appliances. This confirms that both men and women do give importance to colours when they do their shopping, indifferent of the type of products that they are buying. It is also quite interesting to note that women showed a higher interest for colours for digital products like computer, mobile phones and television while men showed a greater interest for colours for products like cooking appliances. This is contradictory to previous findings which found out that men were more interested in colours when it was for digital products while women were more interested in personal products' colours (Akcay, 2013; Akcay, 2012). These findings show that men are also interested in cooking appliances, which was a product, long considered as highly feminine. Products can no longer be positioned to be specific to one particular gender, as both men and women are making use of products, indifferent of its gender attributes and positioning strategies.

It was found out that both genders have at least one favourite colour and it was discovered that having a favourite colour does not depend on someone's gender. All the women from the sample said they had at least one favourite colour while $98.7 \%$ of men replied with the same answer. It is also to be pointed out that Blue was the most favoured colour by both genders. The colour Black was liked for both personal and non-personal products, showing that Black is popular across both genders. It is also interesting to note that products such as clothes, shoes, bags, watches, toothbrush, and umbrellas were mostly selected by respondents for their importance of colours. These products' colours were more focused upon than products like mobile phones, computer, cooking appliances, and television. This concludes that personal products (clothes, shoes, bags, watches) are more important for both genders when it comes to colours. It was also discovered that Blue was the most favoured colour among the respondents. Companies can make use of the colour Blue in their advertisings, their communication strategies, their products, and so on as it is a well-like colour by all people. This can be seen to be the case with a lot of companies in Mauritius such as Swan, Sicom, Alpha Cleaning, SBM, and MBC which make use of the colour Blue. The colour Black was also the second favourite colour and some companies do make use of that colour such as Canal Plus, Regus, Sofitel and others. The colour Orange was the least liked and thus companies need to avoid making use of that particular colour often.

"Love", "warmth", "joy" and "femininity" was associated with Red. It is interesting to note that people associated "femininity" with Red more than Purple, although the colour Purple was second favorite after Red. Moreover, "warmth" and "joy" was also associated with Red, which differs from their previous association with the colours Orange and Yellow respectively (Sliburyte, 2014). "Masculinity", "unhappiness" and "death" was paired up with Black. "Death" is usually associated with black but "unhappiness" is mostly associated with Grey (Akcay, 2013). "Nature" maintained its position as it was paired with the colour Green. On the other hand, "cleanness", "spirituality", "conservative", "calm" and "trust" was associated with the colour White. The associations of "cleanness" and "trust" is in accordance with previous findings (Singh, 2006), but it is interesting to note that "spirituality", which is usually 
associated with Purple, "conservative" which is more commonly associated with the colour Brown, and "calm" which is associated with the colour Blue was also associated with White. The colour Black is used by companies to depict high class and status (Adopt, Vatel, and Celio). Companies who want to be seen as ecological need to make use of the colour Green (Eclosia, Tara, Vivo Energy) and companies who want to be seen as pure, spiritual and sincere need to make use of White. The colour White can also be paired up with the colour Blue. This strategy is mostly used by insurance companies such as Swan, Sicom, LIC and so on. Companies wanting to depict the feeling of joy and happiness need to make use of Red (Coca Cola) and Yellow (Shell). However, it is to be noted that people also associate the colour Black to unhappiness and death, this particular aspect can be made use by funeral planning businesses as this will be in line with the specific meanings associated by the colour.

\section{CONCLUSION}

Colours provide marketers with an innovative way to attract and retain customers. Colours are an effective way to promote your company, improve your visibility, increase your trust value, attract new customers, and so much more. Customers are affected by colours and they make their purchase decisions based on colours. Thus, knowing your customers, their needs and preferences, can help you to better design colours that are in accordance to their beliefs, their personal preference and their purchase decision. Based on the survey, it was found that both men and women are affected by colours and that gender did not impact on most of the statements made prior. Therefore, it was concluded that genders do not play a role in colours and their importance and that both men and women are affected by colours and make their purchase based on colours. Both genders also associated different colours with different meanings and listed their favourite colours. Thus, marketers need to make use of colours when they are marketing to both genders.

Colours such as Blue, Black, Grey and White were noted to be the most popular and marketers need to add those colours to their marketing strategies such as billboards, advertisings, logos and so on. Colours was said to help customers remember particular products, to increase their loyalty, to be a factor for rebuy, to attract their attention, to help in purchase decision, to have different meanings and to be present in the customer's mind at all time. Effective use of colours will lead to a prosperous company image and help in brand equity. It goes along to say that using the right colour at the right time for the right occasion and the right product is the new strategy that marketers need to focus upon.

This research will help marketers to better understand consumers and their behaviours vis-à-vis colours. The results from the survey helps to understand how consumers view colours, how they attribute importance to colours and which products' colours are more important for them. It goes along to say that using the right colour at the right time for the right occasion and the right product is the new strategy that marketers need to focus upon.

\section{LIMITATIONS OF THE STUDY}

Mauritius is a multi-cultural country, thus it would have been interesting to see the results from a cultural view, rather than gender. Although it was discovered that men and women are both attracted to warm and cold colours, it was not found which colours were more memorable for them. Also, colours of famous brands could also have been used as instrument to see whether men and women view colours differently. The gendered marketing can be taken in various directions and applied in different contexts industry wise or product line wise.

\section{DIRECTION FOR FUTURE RESEARCH}

This research sets the ground for future research possibilities of colours and marketing in Mauritius. Future research can take into account the religious or cultural background of the respondents and see if there are any differences between cultures from a marketing perspective of use of colours. An 
investigation on exactly which colours are more memorable for men and women and how they view certain brands' colours can be conducted. Future studies can also find out the opinions of customers on companies' choice and use of colours. This can be helpful, in understanding which colours companies can make use of to gain more visibility and attract a larger audience. Another interesting research is also the gendered marketing of products or services and to see how women and men make their purchases and their unique behaviours.

\section{REFERENCES}

Abrudan, I. N. (2016). Gender and Shopping Behavior Outcomes in the Context of Shopping Centers. Ecoforum, 5(Special Issue).

Akcay, O., Dalgin, M. H., \& Bhatnagar, S. (2011). Perception of Color in Product Choice among College Students: A Cross-National Analysis of USA, India, China and Turkey. International Journal of Business and Social Science, 2(21), 42-48.

Akcay, O. (2012). Marketing to Teenagers: The influence of Color, Ethnicity and Gender. International Journal of Business and Social Science, 3(22), 10-18.

Akcay, O., Sable. P., \& Dalgin, M. H. (2012). The Importance of Color in Product Choice among young Hispanic, Caucasian, and African-American Groups in the USA. International Journal of Business and Social Science, 3(6).

Akcay, O. (2013). Product Color Choice and Meanings of Color: A Case of Germany. International Journal of Business and Social Science, 4(14), 5-12.

Akcay, O., \& Qion. S. (2013). Cross Cultural Analysis of Gender Difference in Product Color Choice in Global Markets. Journal of International Business and Cultural Studies, 7, 158-170.

Alreck, P. (1994). Commentary: A New Formula for Gendering Products and Brands. Journal of Product and Brand Management, 3(1), 6-18.

Amsteus, M., Al-Shaaban, S., Wallin, E., \& Sjöquist, S. (2015). Colors in Marketing: A Study of Color Association and Context (in) Dependence. International Journal of Business and Social Science, 6(3), 32-45.

Aslam, M. (2006). Are You Selling the Right Colour? A Cross Cultural Review of Colour as a Marketing Cue. Journal of Marketing Communications, 12(1), 15-30.

Auster, C., \& Mansbach, C. (2012). The Gender Marketing of Toys: An Analysis of Color and Type of Toy on the Disney Store Website. Sex Roles, 67, 375-388.

Babin, B. J., Hardesty, D. M., \& Suter, T. A. (2003). Color and Shopping Intentions: The intervening effect of price fairness and perceived affect. Journal of Business Research, 56, 541-551.

Babolhavaeji, M., Vakilian. M. A., \& Slambolchi, A. (2015). Colour Preferences Based on Gender as a New Approach to Marketing. Journal of Advanced Social Humanities and Management, 2(1), 35 $-44$.

Babolhavaeji, M., Vakilian, M. A., \& Slambolchi, A. (2015). The Role of Product Color in Consumer Behavior. Advanced Social Humanities and Management, 12(1), 9-15.

Banyte, J., Rūtelionè, A., \& Jarusevirciūte, A. (2015). Modeling of Male Shoppers Behavior in Shopping Orientation Context. Journal of Social and Behavioral Sciences, 213, 694-701.

Boyd, H. W., Westfall. R., \& Stasch, S. F. (1996). Marketing Research: Text and Cases, $7^{\text {th }}$ Edition. Delhi: Laxman Chand Arya.

Chang, W-L., \& Lin, H-L. (2010). The impact of color traits on corporate branding. African Journal of Business Management, 4(12), 3344 - 3355.

Clarke, I., \& Honeycutt, E. D. (2000). Color Usage in International Business - to - Business Print Advertising. Industrial Marketing Management, 29, 255-261.

Collins, G. (1984). New Studies on 'Girl Toys' and 'Boy Toys'. USA: New York Times, 380.

Cunningham III, L.T., Brorsen, B. W., Anderson, K. B., \& Tostâo, E. (2008). Gender Differences in Marketing Styles. International Association of Agricultural Economists, 38(1), $1-7$. 
Dennis, C., Fenech, T., \& Merrilees, B. (2004). E-retailing. USA \& Canada: Routledge, 351-352.

Ethel, L. (2013). Impacts of Social Media on Consumer Behavior - Decision Making Process. BBA. Turku University of Applied Sciences.

Fischer, E., \& Arnold, S. J. (1990). More Than a Labor of Love: Gender Roles and Christmas Gift Shopping. Journal of Consumer Research, 17(3), 333-345.

Fodness, M. (1996). Product Gender Perceptions: the Case of China. International Marketing Review, 13(4), 40-51.

Fugate, D., \& Phillips, J. (2010). Product gender perceptions and antecedents of product gender congruence. Journal of Consumer Marketing, 27(3), 251-261.

Grohmann, A. (2015). Consonants in brand names influence brand gender perceptions. European Journal of Marketing, 49(1/2), 101-122.

Herrmann, T. (2015). The effect of brand design on brand gender perceptions and brand preference. European Journal of Marketing, 49(1/2), 146-169.

Hu, H., \& Jasper, C. R. (2004). Men and Women: A Comparison of Shopping Mall Behavior. Journal of Shopping Center Research, 11(2), 113-123.

Kauppinen - Räisänen, H., \& Luomala, H. T. (2010). Exploring consumers' product specific color meanings. Qualitative Marketing Research, 13(3), 287-308.

Kaya, N., \& Epps, H. (2004). Relationship between Color and Emotion: A Study of College Students. College Student Journal, 38(3), 396-403.

Kempf, D. S., Palan, K. M., \& Laczniak, R. N. (1997). Gender Differences in Information Processing Confidence in an Advertising Context: a Preliminary Study. Advances in Consumer Research, 24, 443-449.

Kerckhove, A. V., \& De Bock, T. (2014). To Contrast or Not to Contrast? Consumers' Response to Color Combinations. Advances in Consumer Research, 42, 716-719.

Khouw, N. (2002). The meaning of color for gender. Colors Matters - Research Available at www.colormatters.com

Kotler, P., \& Keller, K. (2011). Marketing Management, $14^{\text {th }}$ Edition. London: Pearson Education.

Kumar, R. V., \& Joshi, R. (2007). Colour, Colour Everywhere: In Marketing Too. SCMS Journal of Indian Management, 40-46.

Labrecque, L., \& Milne, G. (2012). Exciting Red and Competent Blue: The Importance of Color in Marketing. Journal of the Academy of Marketing Science, 40(5), 711 - 727.

Malhotra, N. K., \& Birks. D. F. (2003). Marketing Research; An Applied Approach, $3^{\text {rd }}$ Edition. Spain: Prentice Hall.

Meyers-LEVY, J., \& Maheswara, D. (1991). Exploring Differences in Males' and Females' Processing Strategies. Journal of Consumer Research, 18(1), 63-70.

Meyers-Levy, J., \& Sternthan, B. (1991). Gender Differences in the Use of Message Cues and Judgments. Journal of Marketing Research, 28(1), 84-96.

Miller, E. G., \& Kahn, B. E. (2005). Shades of Meaning: The Effect of Color and Flavor Names on Consumer Choice. Journal of Consumer Research, 32, 86-92.

Mitchell, V. W., \& Walsh, G. (2004). Gender differences in German consumer decision-making styles. Journal of Consumer Behaviour, 3(4), 331-346.

Mofarah, M. Y., Tahmtan, Z. S., Dadashi, M. T., \& Banihashemian, S. H. (2013). How Color Affects Marketing. Arabian Journal of Business and Management Review (OMAN Chapter), 2(6), $163-171$.

Ndubisi, N. O. (2005). Gender Differences in Customer Behavioural Responses to Sales Promotion. Asia Pacific Management Review, 10(3), 175-185.

Nezhad, Z. H., \& Kavehnezah, K. (2013). Choosing the Right Color: A Way to Increase Sales. International Journal of Asian Social Science, 3(6), 1442-1457. 
Robertson, K., \& Davidson, J. (2013). Gender-role Stereotypes in Integrated Social Marketing Communication: Influence of Attitudes towards the Ad. Australasian Marketing Journal, 21(3), $168-175$.

Sakamoto, K. (2013). Difference in the Color Preference by a Geographical Factor. International Journal of Humanities and Social Sciences, 7(11), 2867-2871.

Sethna, B. N., \& Groeneveld, L. (1984). Research Methods in Marketing and Management. New Delhi: Tata McGraw Hill Publishing Company Limited.

Singh, S. (2006). Impact of Color on Marketing. Management Decision, 44(6), 783-789.

Sliburyte, L., \& Skoryte, I. (2014). What We Know About Consumers' Color Perception. Journal of Social and Behavioral Sciences, 156, 468-472.

Solomon, M. R., \& Rabolt, N. J. (2004). Consumer Behavior in Fashion. USA: Pearson Education, 353- 354.

Tanner. J., \& Raymond, M. A. (2010). Principles of Marketing. Boston: Flat World Knowledge, Inc.

Thorsteinsson, T., \& Ha, J. G. (2012). Using Colours to alter Consumer Behaviour and Product Success. International Journal of Contents, 8(1), 69-73.

Westland, S., \& Shin, M. J. (2015). The relationship between consumer colour preferences and product colour choices. Journal of the International Colour Association, 14, 47-56.

Ulrich, I., \& Desbordes, E. T. (2013). The relevance of multifactorial gender and its measure in marketing. Journal de Recherche et Applications en Marketing, 28(2), 86-115.

Zailskaitè-Jakšte, L., Ostreika, A., Jakštas, A., Stanevičienė, E., \& Damaševičius, R. (2017). Brand communication in social media: the use of image colours in popular posts. 40th International Convention on Information and Communication Technology, Electronics and Microelectronics, $1605-1610$.

Zhang, S. (2015). Color associations with masculine and feminine brand personality among Chinese consumers. MSc. Concordia University. 